\title{
SOIL CHEMICAL ATTRIBUTES IN RESPONSE TO TREE DISTANCE AND SUN-EXPOSED FACES AFTER THE IMPLANTATION OF AN INTEGRATED CROP-LIVESTOCK-FORESTRY SYSTEM ${ }^{1}$
}

\author{
Guilherme Musse Moreira², Júlio César Lima Neves², Ciro Augusto de Souza Magalhães ${ }^{3}$, Austeclinio \\ Lopes de Farias Neto ${ }^{3}$, Geronimo Sauer ${ }^{4}$, João Flávio Veloso Silva ${ }^{3}$ and Raphael B.A. Fernandes ${ }^{2 *}$
}

\footnotetext{
${ }^{1}$ Received on 23.10.2017 accepted for publication on 11.06.2018.

${ }^{2}$ Universidade Federal de Viçosa, Departamento de Solos, Viçosa, MG-Brasil. E-mail: <guilhermemusse@hotmail.com>, <julio_n2003@yahoo.com.br>, and<raphael@ufv.br>.

${ }^{3}$ Empresa Brasileira de Pesquisa Agropecuária, Embrapa Agrossilvipastoril, Sinop, MT-Brasil. E-mail:<ciro.magalhaes@embrapa.br>, $<$ austeclinio.farias@embrapa.br> and <joao.veloso@embrapa.br>.

${ }^{4}$ Universidade Federal de Mato Grosso, Programa de Pós-Graduação em Agronomia, Alta Floresta, MT-Brasil. E-mail: <gero_sauer@hotmail.com>.

*Corresponding author.
}

\begin{abstract}
The use of trees in integrated crop-livestock-forestry systems (ICLF) allows diversifying production, increasing profitability per area, and providing a higher animal comfort. However, the influence of tree component on soil chemical attributes in this system is still little studied. This study aimed to assess the effect of trees and sun-exposed faces to solar radiation on soil nutrient availability at different distances of tree rows in an integrated crop-livestock-forestry system. This study was carried out in the northern Mato Grosso State, Brazil, in the Cerrado - Amazon Forest transition region in an ICLF with the tree component formed by three eucalyptus rows. The assessment carried out in the second year of ICLF implantation considered the effect of tree distances $(3,6,10$, and $15 \mathrm{~m})$ on two sun-exposed faces to solar radiation (north and south) on the main soil chemical attributes. Soil sampling was performed at depths of $0-0.05,0.05-0.10,0.10-0.20$, and $0.20-0.30 \mathrm{~m}$. The results indicated a homogeneity of the average nutrient contents obtained in the north and south-exposed faces, as well as in the comparison of the same distances in both assessed sun-exposed faces. Effects of trees on soil chemical attributes were verified only when an isolated analysis was carried out in the north-exposed face for $\mathrm{K}$ and $\mathrm{Al}$ contents. For these attributes, the increased distance in the row was associated with a reduction in their contents in the more superficial and deeper layers, respectively. Trees do not significantly affect soil nutrient availability in the first years of ICLF implantation in systems with homogeneity of solar radiation incidence in the sun-exposed faces although there may be discrete nutrient reductions with the distance of trees.
\end{abstract}

Keywords: Nutrients; Agrosilvopastoral system; Spatial variability.

\section{ATRIBUTOS QUÍMICOS DO SOLO EM RESPOSTA À DISTÂNCIA DAS ÁRVORES E FACE DE EXPOSIÇÃO SOLAR APÓS A IMPLANTAÇÃO DE INTEGRAÇÃO LAVOURA, PECUARIA E FLORESTA}

RESUMO - A inserção das árvores em sistemas de integração lavoura, pecuária e floresta (ILPF) permite diversificar a produção, aumentar a rentabilidade por área e proporcionar maior conforto animal. Entretanto, a influência do componente arbóreo sobre os atributos químicos do solo neste sistema ainda é pouco estudada. Neste estudo, objetivou-se avaliar o efeito das árvores e das faces de exposição solar sobre a disponibilidade de nutrientes no solo em diferentes distâncias de renques de árvores em um sistema de integração lavoura pecuária floresta. O trabalho foi realizado no norte do estado do Mato Grosso, em região de transição Cerrado/ Floresta Amazônica em um sistema ILPF com o componente arbóreo formado por renques de três linhas de eucalipto. A avaliação efetuada no segundo ano de implantação do sistema ILPF considerou o efeito da distância das árvores (3, 6, 10 e 15 m) em duas faces de exposição solar (norte e sul) sobre os principais 
atributos químicos do solo. A amostragem do solo foi efetuada nas profundidades de 0-0,05; 0,05-0,10; 0,10-0,20 e 0,20-0,30 m. Os resultados indicaram homogeneidade dos teores médios de nutrientes obtidos nas faces norte e sul, bem como na comparação das mesmas distâncias nas duas faces de exposição avaliadas. Efeitos das árvores sobre os atributos químicos do solo foram verificados apenas quando da análise isolada na face norte para os teores de Ke Al. Para esses atributos, o aumento da distância do renque foi associado à redução dos teores nas camadas mais superficiais e mais profundas, respectivamente. A disponibilidade de nutrientes no solo não é afetada significativamente pelas árvores nos primeiros anos de implantação do sistema ILPF em sistemas em que há homogeneidade na incidência de raios solares nas faces de exposição, ainda que possa reduções discretas de nutrientes com o distanciamento das árvores.

Palavras-Chave: Nutrientes; Sistema agrossilvipastoril; Variabilidade espacial.

\section{INTRODUCTION}

Integrated crop-livestock-forestry systems (ICLF) or agrosilvopastoral systems have received the attention of producers and researchers due to their higher versatility in soil use and productivity considering all the involved components. Among other advantages, these systems are characterized by a higher diversification, intensifying soil use, increasing nutrient cycling, adding carbon in the soil, offering a higher comfort to animals due to the shading of trees, and constituting a source of alternative income (Lemaire et al., 2014; Gil et al., 2015; Oliveira et al., 2015; Weimann et al., 2017).

In these systems, trees are usually planted in larger spacings than in agricultural forest plantations, which reduces the number of plants per hectare, allowing the cultivation of other crops and establishment of livestock between planting rows. Among the main criteria for selection of tree species and spacings in ICLF is the lack of negative effects on the development of other crops (Damásio et al., 2015). The effects of this component can be contrasting. For instance, on the one hand, shading may offer a higher comfort to animals (Karvatte et al., 2016), and on the other hand, it may hinder pasture development (Crestani et al., 2017). However, few studies seek to understand the influence of trees in ICLF on soil chemical attributes in the area adjacent to the row of trees, i.e. in the non-wooded area.

The main effects of trees on soil nutrient dynamics are related to their role as a source and drain (Foli et al., 2014). As a source of nutrients, the action of trees occurs by their deeper roots, which seek nutrients in layers where annual crops cannot reach, with their subsequent availability on the surface by deposition and litter decomposition (Lana et al., 2016; Nascimento et al., 2018). The role of trees as a drain of nutrients is related to their higher growth, with the potential

Revista Árvore. 2018;42(4):e420405 competition with other crops, in addition to the possibility of shading harming the development of crops in the area under the influence of their canopies (Resende et al., 2017). Whether as a source or drain, the largest changes in soil properties are expected to occur at distances close to the trees.

An important factor to be considered for ICLF implantation is the direction of planting rows of trees. Row direction interferes directly with the incidence of radiation and sun exposure, with the formation of more or less sun-exposed faces. These factors are important because they interfere on soil temperature and moisture of the surface layer and hence in the decomposition of deposited litter and release of nutrients (Coelho et al., 2013).

Given its role as a source and/or drain of nutrients, it is reasonable to consider that the use of the tree component in ICLF interferes with the availability of nutrients to crops. This effect differs according to the distance of trees due to litter deposition and exposure face to solar radiation, factors that can interfere with the decomposition of the deposited plant residue. Thus, the monitoring of these changes must be carried out at different distances and on both sides of the planting row of trees.

Therefore, this study aimed to assess the effect of trees on soil nutrient availability at different distances of the row of tree components and sun-exposed face to solar radiation in an integrated crop-livestock-forestry system.

\section{MATERIALAND METHODS}

This study was carried out in the experimental area of the Embrapa Agrosilvopastoral, located in Sinop, northern Mato Grosso State, Brazil, at the geographical

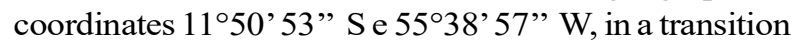
area between the Cerrado and the Amazon. According 
to Köppen classification, regional climate is type Aw, with an average temperature and annual precipitation around $25^{\circ} \mathrm{C}$ and $2,000 \mathrm{~mm}$, respectively (Souza et al., 2013). The altitude is $313 \mathrm{~m}$, with a flat relief and predominance of Oxisol (Latossolo Vermelho-Amarelo distrófico, Brazilian Soil Classification System).

The experimental area was deforested in 1984, being cultivated with cassava, rice, soybean, and corn until 2009, and kept under fallow until 2011, when the experiment was installed. Details on the history of area use are described in Diel et al. (2014).

Before the experiment setup, the soil of the area had the following chemical characteristics at a depth of $0-0.20 \mathrm{~m}: \mathrm{pH}$ in $\mathrm{H}_{2} \mathrm{O}$ of $5.70, \mathrm{Al}^{3+}$ of $0.02 \mathrm{cmol}_{\mathrm{c}} \mathrm{dm}^{-3}$, $\mathrm{H}+\mathrm{Al}$ of $3.80 \mathrm{cmol}_{\mathrm{c}} \mathrm{dm}^{-3}, \mathrm{Ca}^{2+}$ of $2.50 \mathrm{cmol}_{\mathrm{c}} \mathrm{dm}^{-3}, \mathrm{Mg}^{2+}$ of $0.81 \mathrm{cmol}_{\mathrm{c}} \mathrm{dm}^{-3}, \mathrm{CEC}(\mathrm{pH}=7.0)$ of $6.50 \mathrm{cmol}_{\mathrm{c}} \mathrm{dm}^{-3}$, $\mathrm{SB}$ of $2.70 \mathrm{cmol}_{\mathrm{c}} \mathrm{dm}^{-3}$, P of $8.70 \mathrm{mg} \mathrm{dm}^{-3}, \mathrm{~K}$ of $74 \mathrm{mg}$ $\mathrm{dm}^{-3}$, and organic matter of $1.6 \mathrm{dag} \mathrm{kg}^{-1}$. Soil texture is clayey, with $32.2 \%$ of sand, $11.8 \%$ of silt, and $56.0 \%$ of clay.

The soil $\mathrm{pH}$ of the experimental area was corrected with limestone application and a harrowing in the total area without subsequent soil tillage. The experiment was implemented in October 2011 aiming at assessing an integrated crop-livestock-forestry system (ICLF) with the following characteristics: eucalyptus triples rows (Eucalyptus urograndis, clone H13) planted in the east-west orientation, spaced at $30 \mathrm{~m}$, and spacing within rows of $3 \times 3 \mathrm{~m}$ between plants. Soybean (Glycine $\max ($ L.) Merr.) was cultivated in the 2011/2012 season and corn intercropped with pasture (Brachiaria brizantha (Hochst.) Stapf. cv. Marandu) in the off-season, both in the interrow of eucalyptus. Soil management followed the no-tillage system.

The experimental design was a randomized block design with four replications. Each experimental unit presented an area of two hectares.

Due to the lack of a specific fertilization model for ICLF, fertilizer doses applied were established according to crops requirements, as in Sousa and Lobato (2004). Until the sampling carried out in November 2012, the following fertilizations were carried out: $63 \mathrm{~kg} \mathrm{P}_{2} \mathrm{O}_{5}$ $\mathrm{ha}^{-1}$, followed by a topdressing fertilization with 22.2 $\mathrm{kg} \mathrm{ha}^{-1}$ of $\mathrm{N}$ and $\mathrm{K}_{2} \mathrm{O}$, in October 2011 at planting time. At this same time, soybean received $80 \mathrm{~kg} \mathrm{ha}^{-1}$ of $\mathrm{P}_{2} \mathrm{O}_{5}$ and $\mathrm{K}_{2} \mathrm{O}$. Corn was sown in February 2012 and its planting fertilization consisted of $30.4,106.4$, and $60.8 \mathrm{~kg} \mathrm{ha}^{-1}$ of $\mathrm{N}, \mathrm{P}_{2} \mathrm{O}_{5}$, and $\mathrm{K}_{2} \mathrm{O}$, respectively, followed by a topdressing fertilization of $45 \mathrm{~kg} \mathrm{~N} \mathrm{ha}^{-1}$. A new soybean planting was carried out in October 2012 with $70 \mathrm{~kg}$ $\mathrm{ha}^{-1}$ of $\mathrm{P}_{2} \mathrm{O}_{5}$ and $\mathrm{K}_{2} \mathrm{O}$. Fertilizer doses applied in the eucalyptus followed the recommendations of Andrade (2004). Pasture did not receive any specific and additional fertilization since it was planted together with the offseason corn.

Sampling considered the distance of the tree component and exposure face to solar radiation. Initially, five transects were traced at each block along the triple tree rows, spaced $30 \mathrm{~m}$ from each other. Sampling was carried out in these transects (Figure 1) by collecting samples at 3, 6, 10, and $15 \mathrm{~m}$ from the border of each side of the tree row, corresponding to the north- and south- exposed faces, and at depths of 0-0.05, 0.05$0.10,0.10-0.20$, and $0.20-0.30 \mathrm{~m}$. At each collection positions, within each transect, a single sample was taken from five sub-samples by using an auger. These five sub-samples were taken at points aligned perpendicular to the annual crop row (Figure 1). This procedure was adopted in order to minimize potential variations of soil chemical attributes in no-tillage areas, caused by non-soil disturbance. Subsequently, the simple samples collected in different transects were put together, forming composite samples and representing each position $(3,6,10$, and $15 \mathrm{~m}$ from the border) on each sun-exposed face.

Soil samples were air-dried, sieved in 2-mm sieves, and submitted to the following chemical analyses: exchangeable $\mathrm{Ca}^{2+}, \mathrm{Mg}^{2+}$, and $\mathrm{Al}^{3+}$, extracted with 1 mol L-1 $\mathrm{KCl}$ solution and determined by atomic absorption spectrophotometry; available $\mathrm{K}$ and $\mathrm{P}$, extracted by Mehlich-1 solution and determined by flame spectrophotometry and colorimetry (Murphy and Riley, 1962), respectively. All procedures were performed according to Teixeira et al. (2017).

The different sampling positions and sun-exposed faces were treated as treatments. The results were previously submitted to the Shapiro-Wilk and Levene tests to assess the normality and homogeneity of variances, respectively, and, when necessary, the data were transformed. In the assessment of results, three comparisons were performed. The first compared the data sets of sun-exposed faces (north vs. south), the second compared the means of each position on the different sun-exposed faces ( $3 \mathrm{~m}$ south vs. $3 \mathrm{~m}$ north, $6 \mathrm{~m}$ south vs. $6 \mathrm{~m}$ north, etc.), and the third compared the means of positions within the same sun-exposed face

Revista Árvore. 2018;42(4):e420405 


\section{TRANSECTS}

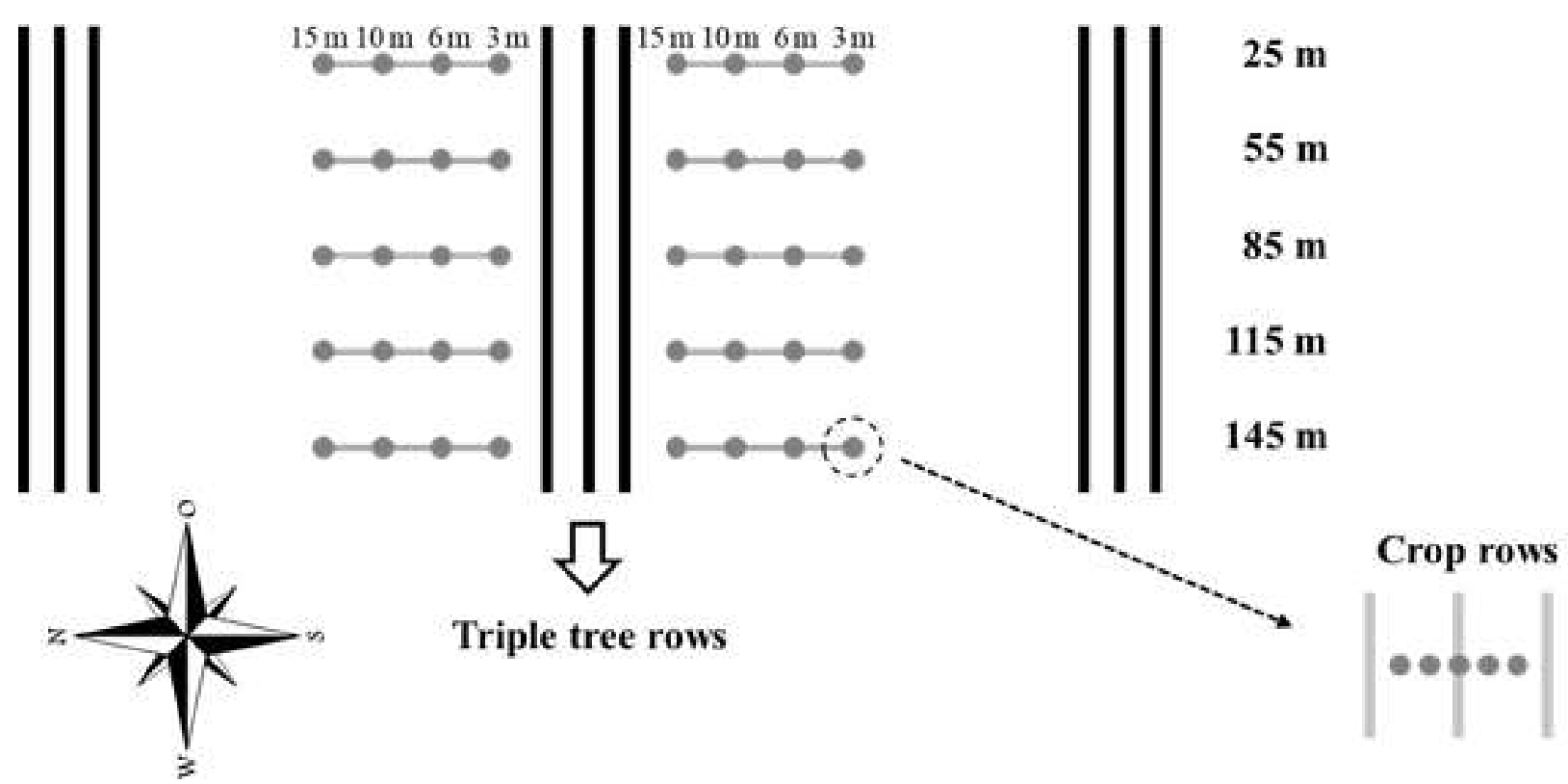

Figure 1 - Representative of the soil sampling procedure in an integrated crop-livestock-forestry system in Sinop, MT, Brazil.

Figura 1 - Croqui representativo do procedimento de amostragem de solo em sistema de integração lavoura, pecuária e floresta em Sinop, MT, Brasil.

( $3 \mathrm{~m}$ vs. $6 \mathrm{~m}$ vs. $10 \mathrm{~m}$ vs. $15 \mathrm{~m}$ ). In the first two comparisons, the analysis of variance (ANOVA) was performed. In the third comparison, when the F-test proved to be significant, a regression analysis was carried out in order to assess gradients of chemical contents in response to the increased distance from the border of the row.

\section{RESULTS}

\subsection{Comparison of sun-exposed faces: north vs. south}

The analysis of both sun-exposed faces considered the average values of soil chemical attributes obtained at all positions from each side of the row. The results indicated a similarity between sun-exposed faces for most of the assessed attributes (Table 1). Differences were only observed for $\mathrm{Ca}$ in at depths of 0.0-0.05 and 0.1-0.2 $\mathrm{m}$ and for $\mathrm{P}$ and $\mathrm{K}$ at a depth of $0.1-0.2 \mathrm{~m}$, with the average contents of these nutrients being higher on the south-exposed face.

\subsection{Comparison between distances on different sun- exposed faces ( $3 \mathrm{~m}$ south vs. $3 \mathrm{~m}$ north, etc.)}

Most of the assessed soil chemical attributes were not influenced by sun-exposed faces and distance from the border of the rows. Variability was only observed in a few positions in the comparison between the northand south-exposed faces, with higher values associated with the south-exposed face (Table 2).

In the most superficial layer $(0.0-0.05 \mathrm{~m}), \mathrm{P}$ and $\mathrm{K}$ contents were higher on the south-exposed face when compared to the north at the positions of 6 and $15 \mathrm{~m}$, respectively. The contents of $\mathrm{K}$ at the position of $3 \mathrm{~m}$, in turn, were higher on the north-exposed face. Regarding the depth of $0.05-0.1 \mathrm{~m}$, while K contents were higher on the south-exposed face at the position of $15 \mathrm{~m}, \mathrm{Al}^{3+}$ contents were higher on the north-exposed face at the distance of $6 \mathrm{~m}$ from the row.

The deepest layers $(0.1-0.2$ and $0.2-0.3 \mathrm{~m})$ showed a higher variability, with a difference for all nutrients at the position of $6 \mathrm{~m}$. At this distance, a better soil chemical quality was verified on the south-exposed face, with higher contents of $\mathrm{P}, \mathrm{K}, \mathrm{Ca}$, and $\mathrm{Mg}$. At a depth of $0.1-0.2 \mathrm{~m}$, the best soil chemical quality of the south-exposed face was also expressed by lower $\mathrm{Al}^{3+}$ contents. At this same depth, even higher $\mathrm{K}$ contents were found at the position of $15 \mathrm{~m}$ of the south-exposed face (Table 2).

Revista Árvore. 2018;42(4):e420405 
Table 1 - Chemical characterization of soil samples taken at different depths on both sun-exposed faces (north and south) of the tree component of an integrated crop-livestock-forestry system in Sinop, MT, Brazil.

Tabela 1 - Caracterização química de amostras de solos retiradas em diferentes profundidades em ambas faces de exposição solar (norte e sul) do componente arbóreo de um sistema de integração lavoura, pecuária e floresta, em Sinop, MT, Brasil.

\begin{tabular}{|c|c|c|c|c|c|c|c|c|c|c|}
\hline \multirow{2}{*}{$\begin{array}{l}\text { Exposed } \\
\text { face }\end{array}$} & $\mathrm{P}$ & $\mathrm{K}$ & $\mathrm{Ca}^{2+}$ & $\mathrm{Mg}^{2+}$ & $\mathrm{Al}^{3+}$ & $\mathrm{P}$ & K & $\mathrm{Ca}^{2+}$ & $\mathrm{Mg}^{2+}$ & $\mathrm{Al}^{3+}$ \\
\hline & \multicolumn{2}{|c|}{$\mathrm{mg} \mathrm{dm}^{-3}$} & \multicolumn{3}{|c|}{$\mathrm{cmol}_{\mathrm{c}} \mathrm{dm}^{-3}$} & \multicolumn{2}{|c|}{$\mathrm{mg} \mathrm{dm}{ }^{-3}$} & \multicolumn{3}{|c|}{$\mathrm{cmol}_{\mathrm{c}} \mathrm{dm}^{-3}$} \\
\hline \multicolumn{6}{|c|}{$0.0-0.05 \mathrm{~m}$} & \multicolumn{5}{|c|}{$0.1-0.2 \mathrm{~m}$} \\
\hline South & 22.7 & 109.7 & $2.1 \mathrm{a}$ & 0.7 & 0.1 & $4.9 \mathrm{a}$ & 54.3a & 1.0 & 0.3 & 0.2 \\
\hline North & 18.2 & 107.5 & $2.0 \mathrm{~b}$ & 0.7 & 0.1 & $2.8 b$ & 46.6b & 1.0 & 0.3 & 0.3 \\
\hline \multirow[t]{2}{*}{$\mathrm{CV}(\%)$} & 31.2 & 14.8 & 9.3 & 8.3 & 38.8 & 41.5 & 19.8 & 17.2 & 12.0 & 31.9 \\
\hline & \multicolumn{3}{|c|}{$0.05-0.10 \mathrm{~m}$} & & & \multicolumn{5}{|c|}{$0.2-0.3 \mathrm{~m}$} \\
\hline South & 13.3 & 75.0 & 1.5 & 0.4 & 0.2 & 2.6 & 40.5 & 0.7 & 0.2 & 0.3 \\
\hline North & 11.4 & 73.4 & 1.5 & 0.4 & 0.3 & 2.2 & 38.0 & 0.7 & 0.2 & 0.4 \\
\hline CV(\%) & 27.9 & 15.0 & 10.0 & 9.6 & 39.3 & 29.8 & 9.3 & 19.6 & 15.4 & 27.7 \\
\hline
\end{tabular}

In the same depth, means followed by the same letters in the column do not significantly differ by the F-test $(\mathrm{p}<0.05)$. CV $=$ coefficient of variation.

\subsection{Comparison between distances on the same sun- exposed face}

The assessment of contents of soil chemical attributes within each sun-exposed face sought to assess the occurrence of some chemical gradient from the border of the eucalyptus row. No changes were detected in most of the assessed contents of soil chemical attributes as the distance of trees increased on both sun-exposed faces (Table 3 ).

On the south-exposed face, differences were observed only for K contents at a depth of 0.1-0.2 $\mathrm{m}$ although without a clear tendency to establish any

Table 2 - Chemical characterization of soil samples taken at different depths and on different sun-exposed faces and distances from the border of tree rows in an integrated crop-livestock-forestry system in Sinop, MT, Brazil.

Tabela 2 - Caracterização química de amostras de solos retiradas em diferentes profundidades e em diferentes faces de exposição solar e distâncias da borda de renques de árvores em um sistema de integração lavoura, pecuária e floresta, em Sinop, MT, Brasil.

\begin{tabular}{|c|c|c|c|c|c|c|c|c|c|c|}
\hline \multirow[t]{2}{*}{ Position $^{(1)}$} & $\mathrm{P}$ & \multirow[t]{2}{*}{$\mathrm{K}$} & $\mathrm{Ca}^{2+}$ & $\mathrm{Mg}^{2+}$ & $\mathrm{Al}^{3+}$ & \multirow{2}{*}{\multicolumn{2}{|c|}{$\frac{\mathrm{P}}{\mathrm{mg} \mathrm{dm}}$}} & $\mathrm{Ca}^{2+}$ & $\mathrm{Mg}^{2+}$ & $\mathrm{Al}^{3+}$ \\
\hline & $\mathrm{mg} \mathrm{dm}{ }^{-3}$ & & \multicolumn{3}{|c|}{$\mathrm{cmol}_{\mathrm{c}} \mathrm{dm}^{-3}$} & & & \multicolumn{3}{|c|}{$\mathrm{cmol}_{\mathrm{c}} \mathrm{dm}^{-3}$} \\
\hline \multicolumn{6}{|c|}{$0.0-0.05 \mathrm{~m}$} & \multicolumn{5}{|c|}{$0.1-0.2 \mathrm{~m}$} \\
\hline $3 \mathrm{~m} \mathrm{~S}$ & 17.7 & $96.0 \mathrm{~b}$ & 2.0 & 0.7 & 0.1 & 4.5 & 46.3 & 1.0 & 0.3 & 0.3 \\
\hline $3 \mathrm{~m} \mathrm{~N}$ & 19.4 & $125.3 \mathrm{a}$ & 2.0 & 0.7 & 0.1 & 3.4 & 50.8 & 0.9 & 0.3 & 0.4 \\
\hline $6 \mathrm{~m} \mathrm{~S}$ & $31.4 \mathrm{a}$ & 118.8 & 2.3 & 0.7 & 0.1 & $8.9 \mathrm{a}$ & $68.3 \mathrm{a}$ & $1.3 \mathrm{a}$ & $0.4 \mathrm{a}$ & $0.1 \mathrm{~b}$ \\
\hline $6 \mathrm{~m} \mathrm{~N}$ & $17.5 b$ & 122.0 & 2.0 & 0.7 & 0.1 & $2.6 b$ & $48.5 b$ & $0.9 b$ & $0.3 b$ & $0.4 \mathrm{a}$ \\
\hline $10 \mathrm{~m} \mathrm{~S}$ & 21.2 & 112.3 & 2.1 & 0.7 & 0.1 & 4.3 & 49.3 & 1.0 & 0.3 & 0.2 \\
\hline $10 \mathrm{~m} \mathrm{~N}$ & 17.8 & 104.3 & 2.0 & 0.7 & 0.1 & 2.6 & 49.8 & 1.0 & 0.3 & 0.3 \\
\hline $15 \mathrm{~m} \mathrm{~S}$ & 20.3 & $111.8 \mathrm{a}$ & 2.0 & 0.7 & 0.1 & 5.6 & $53.3 \mathrm{a}$ & 1.0 & 0.3 & 0.3 \\
\hline $15 \mathrm{~m} \mathrm{~N}$ & 18.1 & $78.5 b$ & 2.0 & 0.7 & 0.1 & 2.9 & $37.3 b$ & 1.0 & 0.3 & 0.3 \\
\hline Average & 20.4 & 108.6 & 2.0 & 0.7 & 0.1 & 4.3 & 50.4 & 1.0 & 0.3 & 0.3 \\
\hline CV $(\%)$ & 34.6 & 17.3 & 10.8 & 8.5 & 65.4 & 66.2 & 16.9 & 19.9 & 19.2 & 38.4 \\
\hline \multicolumn{6}{|c|}{$0.05-0.1 \mathrm{~m}$} & \multicolumn{5}{|c|}{$0.2-03 \mathrm{~m}$} \\
\hline $3 \mathrm{~m} \mathrm{~S}$ & 11.4 & 69.5 & 1.4 & 0.5 & 0.2 & 2.9 & 38.5 & 0.6 & 0.2 & 0.3 \\
\hline $3 \mathrm{~m} \mathrm{~N}$ & 13.0 & 85.8 & 1.6 & 0.4 & 0.3 & 2.2 & 36.8 & 0.6 & 0.2 & 0.5 \\
\hline $6 \mathrm{~m} \mathrm{~S}$ & 13.2 & 78.3 & 1.6 & 0.5 & 0.2 & $4.0 \mathrm{a}$ & $50.8 \mathrm{a}$ & $0.8 \mathrm{a}$ & $0.3 \mathrm{a}$ & 0.3 \\
\hline $6 \mathrm{~m} \mathrm{~N}$ & 12.6 & 84.3 & 1.5 & 0.4 & 0.2 & $1.4 b$ & $36.5 b$ & $0.6 b$ & $0.2 \mathrm{~b}$ & 0.4 \\
\hline $10 \mathrm{~m} \mathrm{~S}$ & 13.9 & 74.3 & 1.5 & 0.4 & $0.1 \mathrm{~b}$ & 2.4 & 36.0 & 0.7 & 0.2 & 0.3 \\
\hline $10 \mathrm{~m} \mathrm{~N}$ & 10.1 & 68.3 & 1.4 & 0.4 & $0.3 \mathrm{a}$ & 1.6 & 39.3 & 0.7 & 0.2 & 0.3 \\
\hline $15 \mathrm{~m} \mathrm{~S}$ & 14.8 & $78.0 \mathrm{a}$ & 1.7 & 0.4 & 0.2 & 2.2 & 36.8 & 0.6 & 0.2 & 0.4 \\
\hline $15 \mathrm{~m} \mathrm{~N}$ & 10.1 & $55.5 b$ & 1.5 & 0.4 & 0.2 & 2.0 & 27.3 & 0.7 & 0.2 & 0.3 \\
\hline Average & 12.4 & 74.2 & 1.5 & 0.4 & 0.2 & 2.3 & 37.7 & 0.7 & 0.2 & 0.4 \\
\hline CV (\%) & 39.3 & 18.1 & 16.6 & 13.3 & 45.5 & 48.3 & 17.7 & 21.1 & 21.1 & 31.8 \\
\hline
\end{tabular}

(1) Position: distance and exposed face (S: South; N: North).

In the same position, means followed by the same letters in the column do not significantly differ by the $\mathrm{F}$-test $(\mathrm{p}<0.05)$. CV $=$ coefficient of variation. 
Table 3 - Chemical characterization of soil samples taken from different distances in relation to the eucalyptus row on the north- and south-exposed faces and from four soil depths in an integrated crop-livestock-forestry system in Sinop, MT, Brazil.

Tabela 3 - Caracterização química de solo tomadas em diferentes distâncias em relação ao renque de eucalipto, nas faces de exposição solar norte e sul e em quatro camadas de solo um sistema de integração lavoura pecuária efloresta em Sinop, MT, Brasil.

\begin{tabular}{|c|c|c|c|c|c|c|c|c|c|c|}
\hline \multicolumn{6}{|c|}{ South } & \multicolumn{5}{|c|}{ North } \\
\hline \multirow[t]{2}{*}{ Distance (m) } & $\mathrm{P}$ & $\mathrm{K}$ & $\mathrm{Ca}^{2+}$ & $\mathrm{Mg}^{2+}$ & $\mathrm{Al}^{3+}$ & $\mathrm{P}$ & $\mathrm{K}$ & $\mathrm{Ca}^{2+}$ & $\mathrm{Mg}^{2+}$ & $\mathrm{Al}^{3+}$ \\
\hline & \multicolumn{2}{|c|}{$\mathrm{mg} \mathrm{dm}^{-3}$} & \multicolumn{3}{|c|}{$\mathrm{cmol}_{\mathrm{c}} \mathrm{dm}^{-3}$} & \multicolumn{2}{|c|}{$\overline{\mathrm{mg} \mathrm{dm}} \mathrm{dm}^{-3}$} & \multicolumn{3}{|c|}{$\mathrm{cmol}_{\mathrm{c}} \mathrm{dm}^{-3}$} \\
\hline \multicolumn{11}{|c|}{$0.0-0.05 \mathrm{~m}$} \\
\hline 3 & 17.7 & 96.0 & 2.0 & 0.7 & 0.1 & 19.4 & 125.3 & 2.0 & 0.7 & 0.1 \\
\hline 6 & 31.4 & 118.8 & 2.3 & 0.7 & 0.1 & 17.5 & 122.0 & 2.0 & 0.7 & 0.1 \\
\hline 10 & 21.2 & 112.3 & 2.1 & 0.7 & 0.1 & 17.8 & 104.3 & 2.0 & 0.7 & 0.1 \\
\hline 15 & 20.3 & 111.8 & 2.0 & 0.7 & 0.1 & 18.1 & 78.5 & 2.0 & 0.7 & 0.1 \\
\hline Average & 22.7 & 109.7 & 2.1 & 0.7 & 0.1 & 18.2 & $*$ & 2.0 & 0.7 & 0.1 \\
\hline CV $(\%)$ & 47.7 & 17.5 & 14.3 & 10.9 & 90.6 & 34.8 & 25.9 & 11.0 & 9.5 & 41.7 \\
\hline \multicolumn{11}{|c|}{$0.05-0.1 \mathrm{~m}$} \\
\hline 3 & 11.4 & 69.5 & 1.4 & 0.5 & 0.2 & 13.0 & 85.8 & 1.6 & 0.4 & 0.3 \\
\hline 6 & 13.2 & 78.3 & 1.6 & 0.5 & 0.2 & 12.6 & 84.3 & 1.5 & 0.4 & 0.2 \\
\hline 10 & 13.9 & 74.3 & 1.5 & 0.4 & 0.1 & 10.1 & 68.3 & 1.4 & 0.4 & 0.3 \\
\hline 15 & 14.8 & 78.0 & 1.7 & 0.4 & 0.2 & 10.1 & 55.5 & 1.5 & 0.4 & 0.2 \\
\hline Average & 13.3 & 75.0 & 1.5 & 0.4 & 0.2 & 11.4 & $*$ & 1.5 & 0.4 & 0.3 \\
\hline CV $(\%)$ & 41.1 & 14.9 & 16.2 & 13.4 & 53.2 & 42.0 & 28.0 & 14.0 & 11.4 & 36.6 \\
\hline \multicolumn{11}{|c|}{$0.1-0.2 \mathrm{~m}$} \\
\hline 3 & 4.5 & 46.3 & 1.0 & 0.3 & 0.3 & 3.4 & 50.8 & 0.9 & 0.3 & 0.4 \\
\hline 6 & 8.9 & 68.3 & 1.3 & 0.4 & 0.1 & 2.6 & 48.5 & 0.9 & 0.3 & 0.4 \\
\hline 10 & 4.3 & 49.3 & 1.0 & 0.3 & 0.2 & 2.6 & 49.8 & 1.0 & 0.3 & 0.3 \\
\hline 15 & 5.6 & 53.3 & 1.0 & 0.3 & 0.3 & 2.9 & 37.3 & 1.0 & 0.3 & 0.3 \\
\hline Average & 5.8 & $*$ & 1.1 & 0.3 & 0.2 & 2.8 & 46.6 & 1.0 & 0.3 & 0.3 \\
\hline CV $(\%)$ & 78.2 & 26.6 & 24.3 & 18.4 & 56.4 & 34.9 & 26.6 & 21.7 & 19.1 & 27.8 \\
\hline \multicolumn{11}{|c|}{$0.2-03 \mathrm{~m}$} \\
\hline 3 & 2.9 & 38.5 & 0.6 & 0.2 & 0.3 & 2.2 & 36.8 & 0.6 & 0.2 & 0.5 \\
\hline 6 & 4.0 & 50.8 & 0.8 & 0.3 & 0.3 & 1.4 & 36.5 & 0.6 & 0.2 & 0.4 \\
\hline 10 & 2.4 & 36.0 & 0.7 & 0.2 & 0.3 & 1.6 & 39.3 & 0.7 & 0.2 & 0.3 \\
\hline 15 & 2.2 & 36.8 & 0.6 & 0.2 & 0.4 & 2.0 & 27.3 & 0.7 & 0.2 & 0.3 \\
\hline Average & 2.9 & 40.5 & 0.7 & 0.2 & 0.3 & 1.8 & 34.9 & 0.6 & 0.2 & $*$ \\
\hline CV $(\%)$ & 55.6 & 25.8 & 27.6 & 21.6 & 43.9 & 38.4 & 23.6 & 26.3 & 21.5 & 33.2 \\
\hline
\end{tabular}

(*) Significant by the F-test (ANOVA), with differences between distances within the same sun-exposed face evaluated by regression equations (Figure 2$)$. CV = coefficient of variation.

relation with the eucalyptus row (Figure 1A). For this nutrient, higher contents were observed at the distance of $6 \mathrm{~m}$, while the lowest contents were observed at the positions of 3 and $10 \mathrm{~m}$.

Gradients in $\mathrm{K}$ and $\mathrm{Al}$ contents were also observed on the north-exposed face. For both chemical attributes, the gradient indicated a linear reduction of contents as the distance from rows increased. This result was verified in the most superficial layers $(0.0-0.05$ and $0.05-0.1 \mathrm{~m}$ ) for $\mathrm{K}$ (Figure $2 \mathrm{~B}$ ) and in the most subsurface layer $(0.2-0.3 \mathrm{~m})$ for $\mathrm{Al}$ (Figure $2 \mathrm{C}$ ).

\section{DISCUSSION}

The few differences observed in the average values of the north- and south-exposed faces, as well as in the assessment of the same distances on different sun- exposed faces did not show important practical changes in terms of nutrient contents that could be associated with solar exposure, which is associated with the natural variation of their contents in the soil. These results indicate that the influence of trees and sun-exposed face to solar radiation is homogeneous on both sides of the rows in the first years of ICLF implantation. Possibly, row orientation (east-west) and the practically null slope allowed the solar radiation to be homogeneously distributed in the north and south faces and contributed to the equality in the comparison of soil chemical attributes between the studied sunexposed faces.

The data obtained from the comparison between soil nutrient contents of the north- and south-exposed faces suggest, therefore, that the verified differences are not derived from the row of trees but from other

Revista Árvore. 2018;42(4):e420405 

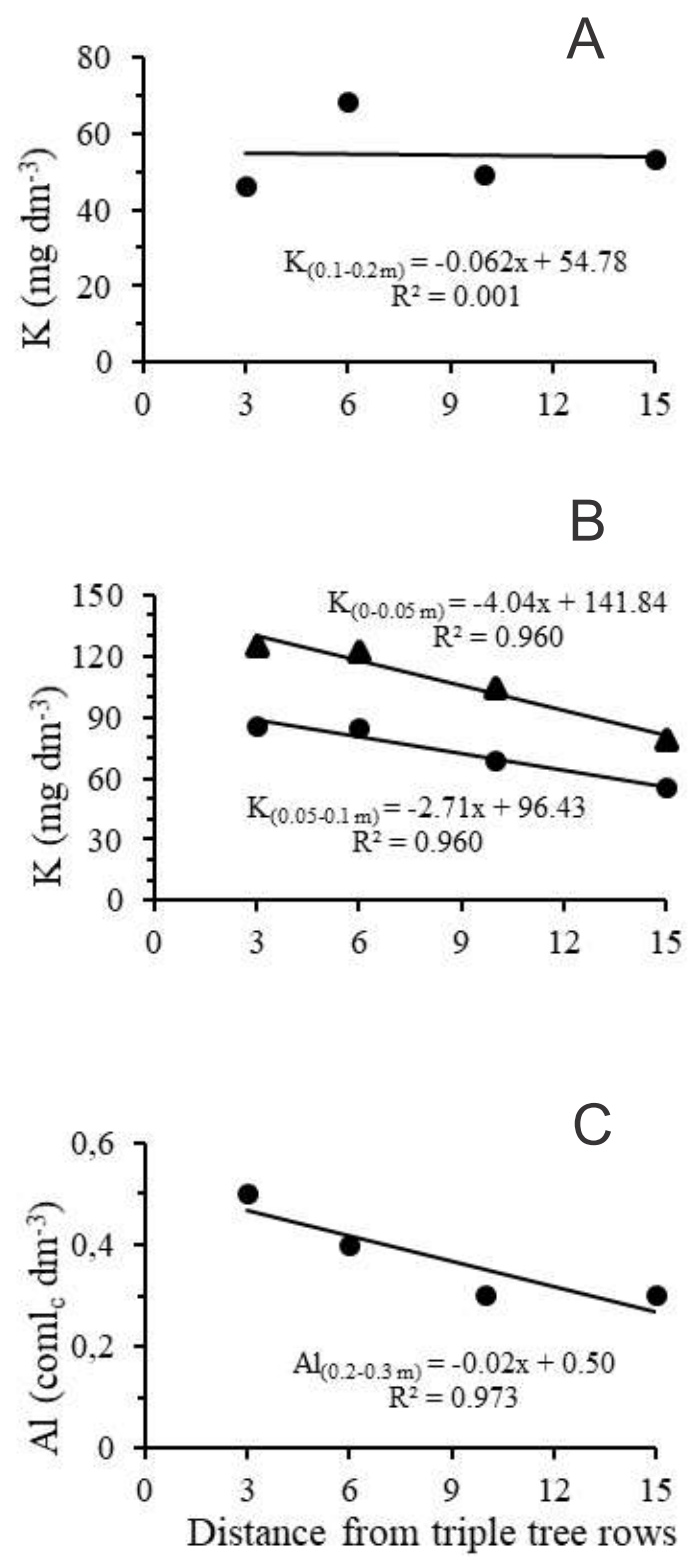

Figure 2 - Variation of $\mathrm{K}$ and Al contents in the soil as a function of the distance of the eucalyptus row in an integrated crop-livestock-forestry system in Sinop, MT, Brazil. (A) K - south-exposed face, 0.1-0.2 m; (B) K - north-exposed face, 0.0-0.05 and $0.05-0.1 \mathrm{~m}$; and $(\mathrm{C}) \mathrm{Al}-$ north-exposed face, $0.2-0.3 \mathrm{~m}$.

Figura 2 - Variação dos teores de Ke Al no solo em função da distância do renque de eucalipto em sistema de integração lavoura pecuária floresta em Sinop, MT, Brasil. (A) $\mathrm{K}$ - face sul 0,1-0,2 m; (B) $\mathrm{K}$ face norte 0,0-0,05 e 0,05-0, $1 \mathrm{~m}$ e (C) Al-face norte $0,2-0,3 \mathrm{~m}$. factors such as differences due to crop fertilization or even some remnant of the management adopted prior to ICLF implantation in the area. Obviously, it is worth noting the short time of implantation of the assessed ICLF, and possible effects can still be expressed in the field in the future with a higher development of the tree component.

The variations observed in $\mathrm{K}$ contents between distances in the north-exposed face are in accordance with the expectation of higher change in the distance of $3 \mathrm{~m}$ of the row, more subject to variations in soil chemical attributes due to the presence and higher proximity of trees (Radomski and Ribaski, 2012). The gradient of contents of this element may be related to litter deposition inversely proportional to the distance of the row, as verified by Freitas et al. (2013). This litter deposition by eucalyptus can achieve, in terms of average total biomass, 4,000 and $10,000 \mathrm{~kg} \mathrm{ha}^{-1}$ at 24 and 26 months of age, respectively, providing at these ages 7.5 to $12 \mathrm{~kg} \mathrm{ha}^{-1}$ (Bellote et al., 2008) or $19.1 \mathrm{~kg} \mathrm{ha}^{-1}$ of $\mathrm{K}$ as the average of four years of cultivation (Viera et al., 2013). However, new in situ assessments of litter production and deposition by trees would be important to ascertain this assumption.

In addition, the interaction between components in integrated systems is complex so that the effects of intercropping on soil nutrient contents cannot be excluded. Some nutrients, such as $\mathrm{K}$, are released from straw to the soil almost completely in about 100 days (Santos et al., 2014). Other studies indicate that plants growing close to trees have physiological changes due to their presence (Mendes et al., 2013). Such changes may eventually promote changes in nutrient accumulation and release by crop residues and consequent soil nutrient availability.

In relation to $\mathrm{Al}$ content variations, the gradient could be justified by the absorption of bases by eucalyptus roots in the soil closest to the row (Faria et al., 2009), which would increase Al activity in soil solution and, consequently, its participation in the exchange complex. Faria and Sabino (2007) found a similar result when observing an increase in Al contents as the distance of the remaining eucalyptus stump reduced.

However, this behavior should be diagnosed on both sun-exposed faces and not only on the northexposed face. In addition, this reduction in contents was not observed in all assessed depths, which makes 
it difficult to attribute to the tree component the main role in explaining the obtained results. We also need to consider that eucalyptus trees are young and a preferential and lateral growth in the subsurface can be favored, in this case, for the area out of the row where there is no competition with other eucalyptus trees and also a higher availability of added nutrients by crop fertilization in the interrow. In addition, the gradient of Al contents did not present high practical differences, ranging from 0.27 to $0.47 \mathrm{cmol}_{\mathrm{c}} \mathrm{dm}^{-3}$ with a reduction of the distance from 15 to $3 \mathrm{~m}$ from the border of the row, and both considered as low for the studied soil (Alvarez V. et al., 1999).

A concern should be considered regarding the soil sampling procedure adopted in ICLF as a function of the gradient of $\mathrm{K}$ and $\mathrm{Al}$ contents observed on the north-exposed face. The results indicate that, even with short implantation period, there may be localized changes in the status of soil chemical attributes due to tree presence. Over the years, this situation may interfere with the results of analyses for soil correction and fertilization obtained from conventional sampling procedures. Thus, we should consider the possibility of dealing with areas adjacent to trees in a special way, such as another sample site.

\section{CONCLUSION}

In systems with a homogeneity in solar radiation incidence on the different sun-exposed faces, trees do not significantly affect soil nutrient availability in the first years of ICLF implantation although discrete reductions in nutrient contents can be observed with the distance of trees.

\section{ACKNOWLEDGMENT}

To the National Council for Scientific and Technological Development (CNPq), Coordenação de Aperfeiçoamento de Pessoal e Nível Superior- CAPES Brasil(Finance Code 001), and Brazilian Agricultural Research Corporation (Embrapa) for the financial support.

\section{REFERENCES}

Alvarez V VH, Novais RF, Barros NF, Cantarutti R, Lopes A. Interpretação dos resultados das análises de solo. In: Ribeiro AC, Guimarães P, Alvarez V. VH, organizadores. Recomendações para o uso de corretivos e fertilizantes em Minas
Gerais. 5a aproximação. Viçosa: Comissão de Fertilidade do Solo do Estado de Minas Gerais, 1999.

Andrade L. Corretivos e fertilizantes para culturas perenes e semiperenes. In: Sousa D, Lobato E, organizadores. Cerrado, correção do solo e adubação. $2^{\text {a }}$.ed Brasília: Embrapa; 2004. p.317-66.

Bellote AFJ, Dedecek RA, Silva HD. Nutrientes minerais, biomassa e deposição de serapilheira em plantio de Eucalyptus com diferentes sistemas de manejo de resíduos florestais. Pesquisa Florestal Brasileira. 2008;56:31-41.

Coelho MS, Mendonça ES, Lima PC, Guimarães GP, Cardoso IM. Qualidade da matéria orgânica de solos sob cultivo de café consórciado com adubos verdes. Revista Brasileira de Ciência do Solo. 2013;37:1576-86.

Crestani S, Mascheroni JDC, Vera Geremia E, Carnevalli RA, Mourão GB, Silva SC. Sward structural characteristics and herbage accumulation of Piatã palisade grass (Brachiaria brizantha) in a crop-livestock-forest integration area. Crop Pasture Science. 2017;68:859-71.

Damásio M, Silva FR, Santos AFA, Rondon Neto RM. Desbaste seletivo em um povoamento de Tectona grandis implantado em sistema de integração-lavoura-pecuária-floresta. Biodiversidade. 2015;14(3):74-83.

Diel D, Behling M, Farias Neto AL, Isernhagen ECC. Distribuição horizontal e vertical de fósforo em sistemas de cultivos exclusivos de soja e de integração lavoura pecuária floresta. Pesquisa Agropecuária Brasileira. 2014;49(8):639-47.

Faria GE, Barros NF, Novais RF, Silva IR. Características químicas do solo em diferentes distâncias do tronco de eucalipto e em diferentes profundidades. Revista Árvore. 2009;33:799-810.

Faria G, Sabino D. Características químicas do solo em diferentes distâncias da cepa de eucalipto. Revista Trópica Ciências Agrarias e Biológicas. 2007;1:50-8.

Foli S, Reed J, Clendenning J, Petrokofsky G, Padoch C, Sunderland T. To what extent does the

Revista Árvore. 2018;42(4):e420405 
presence of forests and trees contribute to food production in humid and dry forest landscapes?: a systematic review protocol. Environmental Evidence. 2014;3:15.

Freitas ECS, Oliveira Neto SN, Fonseca DM, Santos MV, Leite HG, Machado VD. Deposição de serapilheira e de nutrientes no solo em Sistema Agrossilvipastoril com eucalipto e acácia. Revista Árvore. 2013;37:409-17.

Gil J, Siebold M, Berger T. Adoption and development of integrated crop-livestockforestry systems in Mato Grosso, Brazil. Agriculture, Ecosystems \& Environment. 2015;199:394-406.

Karvatte N Jr, Klosowski ES, Almeida RG, Mesquita EE, Oliveira CC, Alves FV. Shading effect on microclimate and thermal comfort indexes in integrated crop-livestock-forest systems in the Brazilian Midwest. International Society of Biometeorology. 2016;60:1933-41.

Lana ÂMQ, Lana RMQ, Lemes EM, Reis GL, Moreira GHFA. Influence of native or exotic trees on soil fertility in decades of silvopastoral system at the Brazilian savannah biome. Agroforestry Systems. 2016;92:415-24.

Lemaire G, Franzluebbers A, Carvalho PCF, Dedieu B. Integrated crop-livestock systems: Strategies to achieve synergy between agricultural production and environmental quality. Agriculture,

Ecosystems \& Environment. 2014;190:4-8.

Mendes MMS, Lacerda CF, Cavalcante ACR, Fernandes FEP, Oliveira TS. Desenvolvimento do milho sob influência de árvores de pau-branco em sistema agrossilvipastoril. Pesquisa Agropecuária Brasileira. 2013;48:1342-50.

Murphy J, Riley JP. A modified single solution method for the determination of phosphate in natural waters. Analytica Chimica Acta. 1962;27:31-36.

Nascimento CDV, Costa MCG, Toma RS, Cooper M. Plant components of agroforestry system have different contributions to soil fertility. Journal of Agricultural Science. 2018;10(4):381-91.
Oliveira FLR, Cabacinha CD, Santos LDT, Barroso DG, Santos Júnior A, Brant MC, et al. Crescimento inicial de eucalipto e acácia, em diferentes arranjos de integração lavoura-pecuária-floresta. Cerne.2015;21:227-33.

Radomski MI, Ribaski J. Fertilidade do solo e produtividade da pastagem em sistema silvipastoril com Grevillea robusta. Pesquisa Florestal Brasileira. 2012;32:53-62.

Resende CCF, Backes C, Santos AJM, Ferro RAC, Moreira AN, Rosa GG, et al. Integração lavoura pecuária e floresta: Uma visão conceitual. In:Anais da $11^{\text {a }}$ Semana do Curso Zootecnia SEZUS. 2017.

Santos FC, Albuquerque Filho MR, Vilela L, Ferreira GB, Carvalho MCS, Viana JHM.

Decomposição e liberação de macronutrientes da palhada de milho e braquiária, sob integração lavoura-pecuária no cerrado baiano. Revista Brasileira Ciência do Solo. 2014;38:1855-61.

Sousa D, Lobato E. Calagem e adubação para culturas anuais e semiperenes. In: Sousa D, Lobato E, organizadores. Cerrado correção do solo e adubação. 2º ed Brasília: Embrapa; 2004. p.317-66.

Souza AP, Mota LL, Zamadei T, Martim CC, Almeida FT, Paulino J. Classificação climática e balanço hídrico climatológico no Estado de Mato Grosso. Nativa. 2013;1:34-43.

Teixeira PC, Donagemma GK, Fontana A, Teixeira WG. Manual de métodos de análises de solo. $3^{\circ}$ ed. Brasília, DF: Embrapa; 2017.

Viera M, Schumacher MV, Caldeira MVW. Dinâmica de decomposição e nutrientes em plantio de Eucalyptus urophylla $\times$ Eucalyptus globulus no sul do Brasil. Floresta e Ambiente. 2013;20:351-60.

Weimann C, Farias JA, Deponti G, Deponti G. Viabilidade econômica do componente arbóreo de sistema agrossilvipastoril comparado ao de plantio florestal na pequena propriedade rural. Pesquisa Florestal Brasileira. 2017;37:429-36. 